\title{
Review
}

\section{Addiction and the adrenal cortex}

\author{
Gavin P Vinson and Caroline H Brennan
}

School of Biological and Chemical Sciences, Queen Mary University of London, London E1 4NS, UK

Correspondence

should be addressed

to $G$ P Vinson

Email

g.p.vinson@qmul.ac.uk

\begin{abstract}
Substantial evidence shows that the hypophyseal-pituitary-adrenal (HPA) axis and corticosteroids are involved in the process of addiction to a variety of agents, and the adrenal cortex has a key role. In general, plasma concentrations of cortisol (or corticosterone in rats or mice) increase on drug withdrawal in a manner that suggests correlation with the behavioural and symptomatic sequelae both in man and in experimental animals. Corticosteroid levels fall back to normal values in resumption of drug intake. The possible interactions between brain corticotrophin releasing hormone $(\mathrm{CRH})$ and proopiomelanocortin (POMC) products and the systemic HPA, and additionally with the local CRH-POMC system in the adrenal gland itself, are complex. Nevertheless, the evidence increasingly suggests that all may be interlinked and that $\mathrm{CRH}$ in the brain and brain POMC products interact with the blood-borne HPA directly or indirectly. Corticosteroids themselves are known to affect mood profoundly and may themselves be addictive. Additionally, there is a heightened susceptibility for addicted subjects to relapse in conditions that are associated with change in HPA activity, such as in stress, or at different times of the day. Recent studies give compelling evidence that a significant part of the array of addictive symptoms is directly attributable to the secretory activity of the adrenal cortex and the actions of corticosteroids. Additionally, sex differences in addiction may also be attributable to adrenocortical function: in humans, males may be protected through higher secretion of DHEA (and DHEAS), and in rats, females may be more susceptible because of higher corticosterone secretion.
\end{abstract}

\author{
Key Words \\ - behaviour \\ - corticosteroids \\ - HPA axis \\ - glucocorticoid
}

\section{Introduction}

The purpose of this review is to demonstrate the critical role of the adrenal cortex in addiction and additionally to propose that sex differences in adrenocortical function may contribute to sex differences in addiction. Where it is clear, the sex of experimental animals or of human subjects in the cited studies is stated, although in most cases sex differences were not emphasized.

There is a long history of associating addiction with the adrenal. Indeed, it was well before the adrenocortical hormones were even characterized that morphine toxicity was linked to the adrenal gland. Thus, Lewis (1) and Mackay \& Mackay (2) showed that adrenalectomy increased morphine sensitivity in female rats, and chronic treatment with morphine in males or methadone in either sex produces adrenocortical hypertrophy $(3,4)$. Consequently, there has been interest in the actions of the hormones of the adrenal as possible agents in addiction from the time of their discovery. Treatment with cortisone (the therapeutic corticosteroid of choice at the time) was soon applied in the management of meperidine and morphine withdrawal symptoms in men (5), apparently with beneficial effects, while Lovell associated alcoholism and drug addiction with hypoadrenocorticism (6).

More systematic study then discounted corticosteroids along with other novel 'cures' for withdrawal symptoms, and Fraser \& Isbell (7) were the first to suggest http://www.endocrineconnections.org DOI: 10.1530/EC-13-0028 (c) 2013 The authors Published by Bioscientifica Ltd

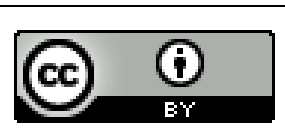

This work is licensed under a Creative Commons Attribution 3.0 Unported License. 
that in fact withdrawal symptoms (from morphine) in men were associated with eosinopaenia, a measure used at that time to reflect high levels of circulating corticosteroids (8). Eosinophil counts swiftly normalized when morphine was restored. These authors also found that treatment with either cortisone or ACTH shortened the period for development of withdrawal symptoms in men, and therefore, they themselves could be considered a cause $(7,9,10,11)$. Indeed, chronic treatment with corticosteroid can itself lead to later withdrawal symptoms (12).

So there are fundamental questions on the role of corticosteroids in addiction. Is the lower adrenocortical activity in sustained morphine administration, and its elevation when administration ceases, a cause or an effect of addictive responses? Could the drive to addictive drugs actually represent a drive to lower cortisol, with its sequelae? Or is the heightened secretion of corticosteroids in drug withdrawal simply a response to stress? We here argue that the adrenal cortex has a critical role in the acquisition of addiction and also in protection against it.

\section{The hypophyseal-pituitary-adrenal axis in the brain and addiction}

In relation to addiction, far more attention has been paid to hypophyseal-pituitary-adrenal (HPA) components in the brain than to the systemic (i.e. blood-borne) HPA axis. All the components are present in the brain, and, in relation to the hypothesis that the adrenal itself is crucial to addiction, it is important to unravel the relationship between brain and systemic HPA function. This section examines the evidence for brain HPA function in addiction and shows that it is not autonomous, and its function is closely regulated by and linked to the systemic HPA.

\section{Corticotrophin releasing hormone}

Corticotrophin releasing hormone $(\mathrm{CRH})$ is produced in various parts of the brain (13). First, CRH exerts its systemic effects following its release at the median eminence by neuronal tracts that originate in the paraventricular nucleus (PVN) of the hypothalamus. $\mathrm{CRH}$ is transported to the corticotrophs of the anterior pituitary via the hypophyseal portal system and then stimulates the secretion of ACTH. ACTH is in turn carried in the general circulation and stimulates the secretion of corticosteroids in the adrenal cortex.
In addition, however, CRH, its receptors CRHR1 and CRHR2, and also CRH binding protein (CRH-BP), which modulates $\mathrm{CRH}$ actions, are found in other brain locations, where CRH presumably acts primarily as a neurotransmitter. These sites include the cerebrocortex, limbic system, hippocampus, amygdala, locus coeruleus, olfactory bulb and cerebellum $(14,15,16,17,18,19,20)$. While the involvement of such extra hypophyseal CRH with addiction may be independent of the HPA $(18,20)$, there are certainly pathways through which it contributes to the multifactorial regulation of hypothalamic CRH (Fig. 1).

In the brain, CRH binds to both receptor types, CRHR1 and CRHR2. In addition to CRH itself, both these receptors bind ligands of the urotensin family. The two receptors mediate different responses; CRHR1 agonists produce stress-related responses on which CRHR2 may have less effect, while more potently depressing food intake $(21,22,23,24)$.

There is certainly substantial evidence for the role of CRH in addiction $(18,25)$, and particularly in reinstatement, but the data are not always consistent. For example, cocaine stimulates the HPA axis through a hypothalamic/CRH-mediated mechanism in male rats $(26,27)$, and although this is not invariably closely linked to corticosterone (28), both Crh mRNA transcription and circulating corticosterone are further increased on cocaine withdrawal (29). In contrast, shock-induced reinstatement of heroin or alcohol seeking clearly depends on $\mathrm{CRH}$, but not on corticosterone, according to some authors $(30,31,32)$. Nevertheless, adrenal function is required during cocaine self-administration for subsequent CRH-dependent shock-induced reinstatement to occur (33). The modulator of CRH actions, CRH-BP, is now emerging as an additional factor, although not so widely studied in the addiction field $(34,35)$. Although both corticosterone and ACTH secretion are increased by acute alcohol exposure, they are inhibited in chronic exposure $(36,37)$. Neither CRH nor cortisol is implicated in cocaine reinstatement in squirrel monkeys (38).

With specific regard to morphine and the opioids, it is clear that reduced circulating corticosteroid concentrations may be a consequence of opioid inhibition of CRH secretion, acting through $\mu$ - and $\kappa$-type opioid receptors in the male rat hypothalamus $(39,40,41)$. In humans, opioids directly inhibit CRH secretion and the HPA axis, resulting in decreased circulating cortisol. In male rats, the effect is biphasic, with early enhancement of $\mathrm{CRH}$ (and the HPA) followed by inhibition after a few days of treatment $(41,42)$; such responses are affected by stress

This work is licensed under a Creative Commons Attribution 3.0 Unported License. 


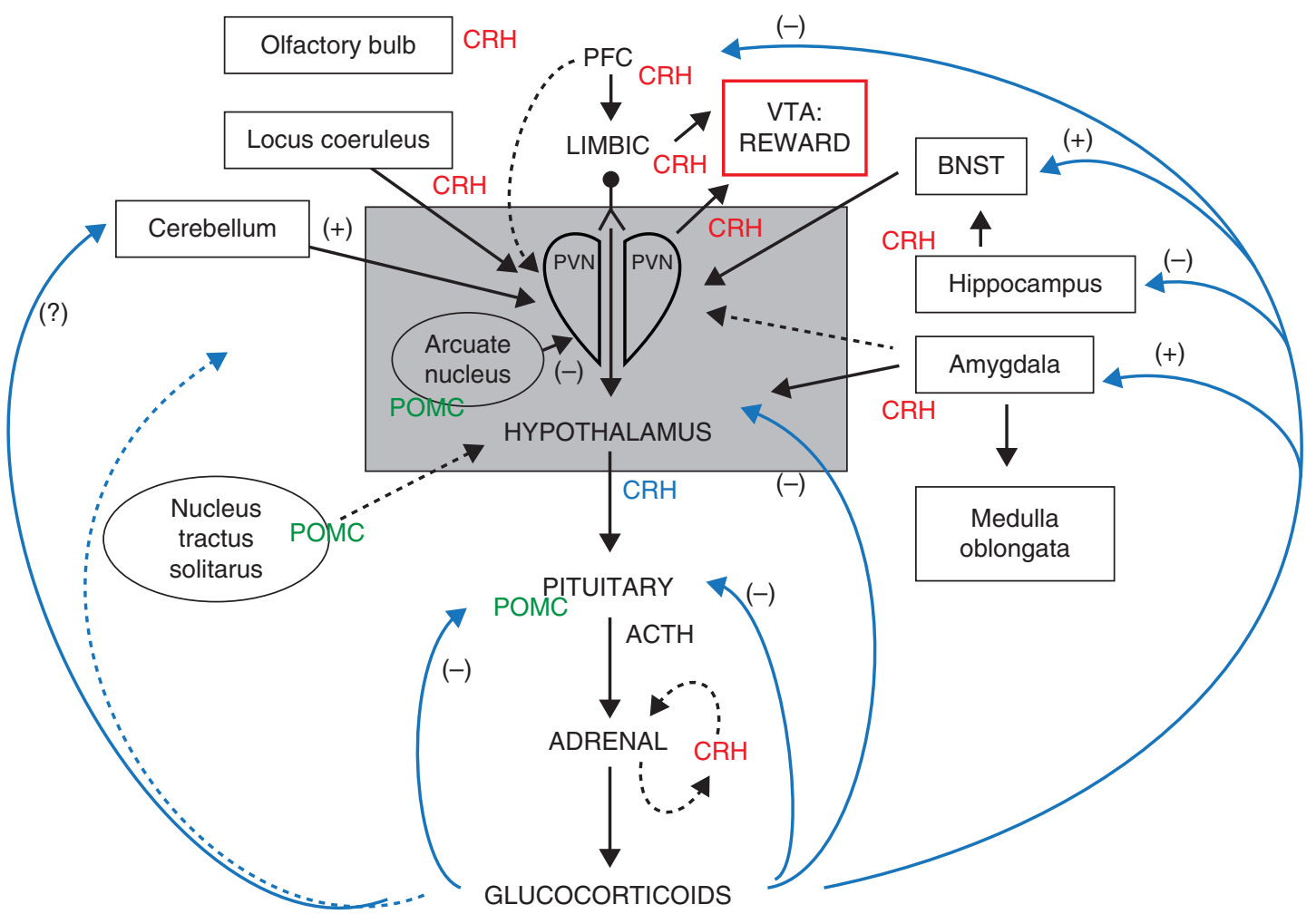

\section{Figure 1}

The expanded HPA axis. From $(20,49,80,82,192,193)$ and see text. BNST, bed nucleus of stria terminalis; PFC, pre-frontal cortex; PVN, paraventricular nucleus; VTA, ventral tegumental area (associated with reward responses); $\mathrm{CRH}$, corticotrophin releasing hormone; POMC, proopiomelanocortin; +, stimulatory; - , inhibitory. Solid arrows show proven regulation, and dotted arrows show postulated actions. Secreted $\mathrm{CRH}$ is indicated in blue lettering, and sites of CRH and POMC signalling are indicated in red and green respectively: here, arrows indicate regulatory pathways that are unquestionably multifactorial but may include actions of
CRH and POMC peptides. The inhibitory effect of neural POMC peptides on PVN CRH is particularly interesting, and, by comparison with other systems, might suggest a negative feedback mechanism; however, there is little evidence for reciprocal feedback of $\mathrm{CRH}$ on POMC in the brain. Instead, regulation of neural POMC is multifactorial (e.g. $(65,67)$, and this is primarily linked to its role in energy balance and nutrition, see text. There is, however, much evidence to show the feedback of glucocorticoids on $\mathrm{CRH}$ expression in several brain regions. Mostly, this is negative, except in the amygdala, a key region in addiction (19), where it is positive. in male rats (43). Indeed, the evidence suggests that opioidergic mechanisms may at least partially underlie both the behavioural effects of CRH in male rats (44) and also the increase in CRH secretion under conditions of stress. This may not be true in other situations such as the increased HPA activity in adrenalectomized animals (45). This double effect in rats may be because opioids have differential effects on different cell types: they certainly inhibit CRH secretion that is promoted by neurotransmitters (46). The possibly critical involvement of opioids in alcohol addiction in humans (47) has also been shown to be exerted via other than HPA pathways (48).

There are clear differences between the actions of different addictive drugs on Crh mRNA transcription in the hypothalamus, and although alcohol acts directly on the PVN, other drugs, including cocaine, nicotine and cannabinoids, activate $\mathrm{Crh}$ transcription in other brain sites (49). Adrenocortical activity may still be critical, for example in reinstatement of cocaine addiction in male rats (33). Timing of exposure is also significant; early exposure can affect subsequent responses (50), and in male rats, adolescent exposure to alcohol vapour blunts subsequent adult Crh transcription response to acute alcohol (51).

The development of specific CRHR1 antagonists has provided more information. CRHR1 blockade inhibits further alcohol drinking in male rats habituated to a high intake (52), and, in conjunction with additional studies using Crh1 knockout animals, it has been shown that CRHR1 signalling pathways are essential for sensitization to alcohol addiction in male mice (53); a common expression of neuroadaptations induced by repeated exposure to addictive drugs is a persistent sensitized 
behavioural response to their stimulant properties. These authors also show that acquisition and sensitization are differentially regulated. Acquisition involves the HPA axis and is inhibited by the glucocorticoid blocker mifepristone as well as by CRHR1 blockade, whereas sensitization is unaffected by mifepristone. Pastor et al. (53) propose that this suggests a non-hypothalamic CRHR1-linked pathway in sensitization. Different effects were seen in methamphetamine (MA) responses, in which behavioural sensitization measured as increased drug-induced locomotor activity was unaffected in Crh1 knockouts or by the antagonist CP 154526 in DBA/2J mice, whereas deletion of Crh2 attenuated MA-induced behavioural sensitization. Here, an action of endogenous urocortins was suggested, focused in the basolateral and central nuclei of the amygdala (54).

\section{Proopiomelanocortin}

Proopiomelanocortin (POMC) provides, in ACTH and $\alpha$-melanocyte stimulating hormone $(\alpha-\mathrm{MSH})$, the other components of the HPA axis, and in this context, its primary site of expression and processing is the anterior pituitary and (in rodents) the pars intermedia. POMC is also expressed in brain sites, primarily in projections from the arcuate nucleus of the hypothalamus and from the nucleus tractus solitarius of the brainstem $(55,56,57)$. Its primary role in the brain is the generation of $\alpha-\mathrm{MSH}$, which participates in the regulation of food intake and in the production of $\beta$-endorphin, pain control. $\alpha$-MSH acts through two of the melanocortin receptor (MCR) series, MC3R and MC4R, and the latter may also regulate aspects of pain recognition $(25,58)$.

POMC expression and processing suggests that although ACTH and other POMC products such as $\beta$-endorphin can be found in non-hypothalamic regions of the brain or cerebrospinal fluid $(59,60)$, some may be transported to the brain from the blood $(60,61)$. From early development, the major adrenocortical-related POMC product in the brain is $\alpha$-MSH (62), presumably associated with the distribution of the prohormone convertases PC1 and PC2 $(63,64)$. By far, the major focus of attention in this regard is the role of $\alpha$-MSH with leptin, ghrelin and agouti protein in the regulation of food intake and energy balance $(56,62,65,66,67,68)$.

In addition to its role in energy balance, $\alpha$-MSH also plays a part in the physiology of addiction, and MC4R, like CRH receptors, respond to morphine $(69,70$, 71 ), and the behavioural effects of morphine or cocaine are modulated by selective MC4R inhibition $(72,73)$.
Additionally, acute alcohol treatment reduced $\alpha$-MSH expression in hypothalamic and other brain locations in rats, but chronic treatment enhanced it (74).

Of course, POMC processing in relation to addiction cannot be considered purely in terms of its HPA-linked functions. The production of $\beta$-endorphin leads inevitably to direct effects on addiction pathways. Its main action is mediated by $\mu$-receptors as are the opiates morphine, heroin and methadone, and in humans, the endogenous opiates are similarly inhibitory on HPA function, although both stimulatory and inhibitory in rats $(49,75)$.

What has not been clear hitherto is whether the term 'HPA axis' can in reality be extended to these components in the brain. In other words, it has been unclear whether, for example, non-hypothalamic CRH provokes synthesis, processing or release of POMC in the brain, but the different locations of the expression of these components may suggest it does not (Fig. 1). Similarly, there has really been no evidence that brain CRH or POMC products have any interaction with the adrenal cortex and the secretion of glucocorticoids, other than via the hypothalamus. On the contrary, it has sometimes been assumed that they do not (e.g. (53)). However, neural glucocorticoid receptor (GR) disruption, including in the PVN, ameliorates the effects of anxiety and also results in heightened HPA activity in male mice (76), consistent with the loss of glucocorticoid inhibition of CRH $(20,77)$. In contrast, forebrain-specific GR knockout, which does not involve the PVN, increased anxiety behaviour but has the same effect of diminishing glucocorticoid inhibition of $\mathrm{CRH}$ in male mice (77). It is clear from this study that the HPA is regulated partly by forebrain GR-mediated inhibition. Accordingly, what needs to be unravelled is the significance of the local brain CRH/POMC components in distinction to that of the systemic HPA, and how independent these systems really are in addiction.

\section{Interaction between brain CRH and $\alpha$-MSH}

Although the main recognized function of $\alpha$-MSH in the brain, regulation of food intake and nutrition seems not to be closely related to that of $\mathrm{CRH}$, in fact there is ample evidence of crosstalk between them. Certainly, like the systemic HPA, POMC-processing neurones are activated by stress and play a role in the consequent behavioural response in male rats $(78,79)$. Furthermore, neuronal POMC-derived peptides regulate hypothalamic $\mathrm{CRH}$ and thus ACTH secretion in male and female mice (80). Additionally, $\alpha$-MSH stimulates Crh transcription in the PVN of male rats $(81,82)$, although, like $\gamma-\mathrm{MSH}$, it also

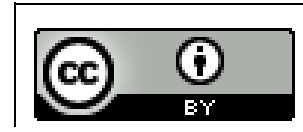

This work is licensed under a Creative Commons Attribution 3.0 Unported License. 
inhibits interleukin-1 $\beta$-induced HPA activity, apparently through central MCRs (83). That the circuit connecting brain and systemic HPA is complete is suggested by the finding that glucocorticoids enhance MC4R signalling in a hypothalamic neuronal cell line (84). We can therefore predict the existence of an extended HPA axis in which the same components, CRH, POMC products and corticosteroids as in the classical system, also interact in the brain (Fig. 1) with specific effects on mood and behaviour. The two systems, brain and somatic, interact to the extent that whatever physiological stimuli activate the systemic system, broadly 'stress' and the clock, must also have consequences on mood and behaviour.

\section{Steroids in the brain}

The spectrum of structures and functions of neurosteroids is so wide as to form a branch of endocrinology (or at least paracrinology) in its own right. Many are locally synthesized, although usually requiring substrates from non-neural sources. Oestrogens are prominent among these and are produced by aromatase activity in the hippocampus, acting, it is thought, on locally produced $\mathrm{C}_{19}$ steroid substrates (85). They have roles in neural plasticity (86) and neuroprotection $(85,87,88)$ and regulate the function of other neurally active agents, including neuroprogesterone, which is also synthesized locally (89). There are sex-related differences in the neural responses to oestrogen $(90,91,92)$. Oestrogen action in the brain is mediated through classical oestrogen receptors $\alpha$ and $\beta$ and also through membrane metabotropic glutamate receptors $(93,94)$. Neuroactive steroids that primarily act through $N$-methyl-D-aspartate or gammaaminobutyric acid (GABA) receptors include the adrenal androgen DHEA, which as DHEAS conjugate is the most abundant steroid in human plasma $(95,96,97,98)$. DHEA is not secreted by the rat adrenal cortex: its presence and activity in the brain reflect its local synthesis (99). DHEA and pregnenolone, both $\Delta^{5}, 3 \beta$-hydrosteroids, are also opioid sigma receptor agonists, whereas progesterone, which has the $\Delta^{4}, 3$-one configuration, is an antagonist (100). Through their sigma-1 agonist actions, pretreatment with DHEA or pregnenolone potentiates cocaine-induced conditioned place preference (CPP) behaviour in mice (100) but attenuates cocaine-seeking behaviour (101). In patients, DHEA and DHEAS are associated with beneficial actions in cocaine withdrawal (102, 103), and the use of DHEA administration to assist opioid withdrawal has been studied, with variable outcomes $(104,105)$.
Other known neurosteroids include $3 \alpha$-hydroxy$5 \alpha$-pregnan-20-one (tertrahydroprogesterone, allopregnanolone, THP) and 3 $\alpha, 21$-dihydroxy-5 $\alpha$-pregnan-20-one (tetrahydrodeoxycorticosterone, THDOC), and they are formed in the brain from progesterone and deoxycorticosterone $(106,107)$. They have anxiolytic, anticonvulsant and sedative activities and are known to be elevated in both plasma and brain in response to ethanol in rats $(106,108)$. In addition, the HPA axis is under tonic GABA inhibition at the hypothalamic level (75). Importantly, production in the brain of both THP and THDOC depends on precursor steroids of adrenal origin (106).

The corticosteroids themselves have neurological effects, and brain concentrations of corticosterone certainly have relevance to addictive behaviour in male rats (109), and see below. However, the relevance of local brain synthesis of corticosteroids is unclear. Certainly, all the required enzymes of the corticosteroid biosynthetic pathway from cholesterol are present, notably in the hippocampus, together with the StAR protein $(110,111$, 112), but their level of production is likely to be low in comparison with concentrations crossing the blood-brain barrier, and they are not thought to be produced in the brain to any great extent $(113,114)$. Remarkably then, of the known neurosteroids, the corticosteroids may fall into a group of their own being predominantly dependent on an extraneural source: the adrenal cortex.

\section{The role of the adrenal cortex}

\section{Corticosteroids and mood}

Clearly, the role of corticosteroids in addiction cannot be understood without reference to the nature of the psychological and behavioural aspects of the actions of corticosteroids themselves. Almost as the corticosteroids were first characterized, their paradoxical capacity to generate both euphoria and depression in humans has been well known, although poorly understood $(115,116)$. Changes in mood are a feature of chronic corticosteroid therapy, with mild euphoria in the short term and increases in severity of symptoms associated with depression, or even psychosis in the long-term, and these occur most frequently in women $(116,117,118$, $119,120)$, although with large variations in incidence in different studies. Moreover, both cortisol levels and the response to ACTH are higher in depression or depressive episodes (121), and animal experiments show that both of these may be linked to high CRH secretion (29). It has been suggested that corticosteroids may have a role in

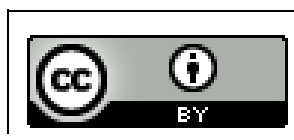

This work is licensed under a Creative Commons Attribution 3.0 Unported License. 
dopamine-related psychiatric disorders (122), and it has also been speculated that some behavioural features in animals and humans may result from structural or other changes in the brain that corticosteroids may invoke, or at least facilitate $(114,123,124)$. Reduction of circulating corticosteroid levels, in combination with other indices, can also be used as a marker for response to anxiolytic therapy $(125,126)$. It has been postulated that depression in fact reflects GR desensitization, giving rise to impaired glucocorticoid feedback at the hypothalamus, hence increased HPA activity. In this model, one action of antidepressants is thus to resensitize GR transcriptional activity (125), independent of their action on monoamine reuptake, but perhaps involving regulation of steroid elimination from the cell through the multi-drug resistance P-glycoprotein membrane transporter system (127, 128). Together, these studies suggest that corticosteroidevoked mood changes could be related to behavioural responses to addiction.

\section{Corticosteroids and addiction}

Although the earlier association between the adrenal cortex and addiction is derived largely from circumstantial evidence, there are now data showing a direct causal link. From their experiences with patients receiving chronic steroid treatment, some authors have been willing to label the corticosteroids as drugs of addiction themselves (129, $130,131,132,133,134)$, although much of the earlier evidence is based on individual case reports. These findings tend to suggest a close link between corticosteroids and addiction, a concept amply borne out by more recent studies. Alcohol administration induces ACTH secretion and thus adrenocortical stimulation in male rats (106). In habituated men smoking high- but not lownicotine cigarettes, increased plasma ACTH and cortisol occurs within minutes of smoking (135). Further evidence for the crucial actions of elevated cortisol is given by its association with impaired learning and memory in abstinent cocaine-dependent men and women (136), although higher basal cortisol levels are associated with improved memory performance in healthy controls. These effects on memory apparently reflect the inverted U-shaped cortisol response curve; at low levels, increased cortisol is beneficial to hippocampal cognitive responses, but at higher levels, it is not (137). The degree of stressinduced cortisolaemia and mood negativity is correlated with increased positivity after amphetamine in men and women (138).
Furthermore, much experimental evidence supports the general concept (see Table 1). Male rats too selfadminister corticosterone in a manner that suggests some degree of dependence $(139,140)$. Thus, de Jong et al. (141) found that cocaine-induced locomotor sensitization in adrenalectomized male mice was restored by replacement of both adrenaline and corticosterone, and cocaine- or alcohol-induced behaviours in female mice are inhibited in the presence of a GR inhibitor (142). Additionally, if corticosteroid synthesis is blocked, cocaine self-administration also relapses according to some authors (143). Others find the reverse that corticosterone facilitates relapse, although dexamethasone did not, suggesting mineralocorticoid receptor (NR3C2, MR) involvement (144). Such effects, like those of antipsychotic drugs, may be mediated through the mesolimbic dopaminergic system (145, 146). It is striking that dopamine-dependent responses to morphine require glucocorticoid receptors (147).

In experimental animals, the definitive evidence for the pivotal role of the corticosteroids in addiction stems from recent studies in the effects of GR over- and underexpression. Brain-specific GR depletion in mice decreased cocaine self-administration, while corticosterone replacement restored it (148). Specific GR disruption in dopaminoceptive but not dopamine neurones decreased cocaine self-administration (149), whereas GR disruption in either type attenuates cocaine-induced CPP, with no effect on morphine-induced behaviour (150). Morphine-induced CPP depends on hippocampal and nucleus accumbens GR (151). In male mice, overexpression of forebrain GR results in heightened sensitization to cocaine as well as anxiety (152).

There is also evidence of the pivotal role of GR in studies of GR polymorphisms in humans, which have revealed association of particular alleles with the initiation of alcohol abuse in female adolescents (153). These and further experimental data that now link addictive behaviour and symptoms with corticosteroids, particularly in response to cocaine, are summarized in Table 1.

\section{Sex differences in addiction}

The possibility of sex differences in responses to drugs of addiction of brain $\mathrm{CRH}, \mathrm{POMC}$, neurosteroids and the HPA axis has not been addressed anywhere in the literature reviewed here. Sometimes, the sex of experimental animals used is not actually given, although this is rare. The impression is that studies are often performed on animals of the same sex - male rats are frequently used - to

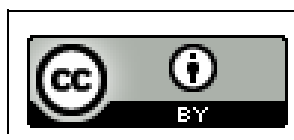

This work is licensed under a Creative Commons Attribution 3.0 Unported License. 
Table 1 Glucocorticoids and addiction. All the direct experimental evidence for the essential role of glucocorticoids has been obtained in experimental animals, as illustrated here. Evidence from the human species is indirect and circumstantial but appears to support the general conclusion that glucocorticoids, regulated by an expanded HPA axis, underlie the important features of addiction.

\begin{tabular}{|c|c|c|c|}
\hline Species & & & \\
\hline \multirow[t]{7}{*}{ Rats $^{a}$} & Corticosterone & Administration & $\begin{array}{l}\text { Up to } 100 \mu \mathrm{g} / \mathrm{ml} \text { in drinking } \\
\text { water } \\
\text { Up to } 50 \mu \mathrm{g} / \text { animal per day }\end{array}$ \\
\hline & & & Up to $0.8 \mathrm{mg} / \mathrm{kg}$ implant \\
\hline & & Stress induced & Novel environment \\
\hline & & & Immobilisation \\
\hline & & Synthesis blocked & By metyrapone $50 \mathrm{mg} / \mathrm{kg}$ \\
\hline & & & By metyrapone $100 \mathrm{mg} / \mathrm{kg}$ \\
\hline & & & $\begin{array}{l}\text { By metyrapone synergistic } \\
\text { with benzodiazepine } \\
\text { agonist oxazepam; up to } \\
45 \mathrm{mg} / \mathrm{kg}: 20 \mathrm{mg} / \mathrm{kg}^{2} \text { i.p.c } \\
\text { By adrenalectomy }\end{array}$ \\
\hline
\end{tabular}

Mice $^{\mathrm{b}} \quad \mathrm{GR}$
Levels in blood

Levels in brain

With corticosterone hemisuccinate replacement; up to $3 \mathrm{mg} / \mathrm{kg}$ implant$$
\text { depletion }
$$

Selective GR overexpression

Adrenalectomy

Antagonist, mifepristone $30 \mathrm{mg} / \mathrm{kg}$ i.p. (or, less effective, MR antagonist spironolacetone $20 \mathrm{mg} / \mathrm{kg}$ i.p.)

In brain

In brain

In dopaminoceptive neurones

In dopaminoceptive or dopamine neurones

In forebrain

With corticosterone $(20 \mathrm{mg}$

\section{In}

Induced corticosterone self administration

Induced corticosterone self administration

Induced corticosterone self administration

Induced amphetamine self administration

Impaired HPA feedback in cocaine habituated animals

Reduced psychomotor effects of cocaine, and reduced reinstatement

Reduced psychomotor effects of cocaine, and reduced reinstatement

Reduced psychomotor effects of cocaine, and reduced reinstatement

Cocaine reinstatement reduced, restored by corticosterone replacement

Reduced Fos response to dopamine agonist, enhanced dopamine response to cocaine

Decreased cocaine-induced locomotor sensitisation

Restoration of cocaine-induced sensitisation

Unrelated to high or low responder to cocaine classification

Related to high or low responder to cocaine classification

Reduced cocaine induced reinforcement

Reference 139 in pellets) and adrenaline (5 $\mu \mathrm{g} / \mathrm{kg}$ s.c.) replacement

Decreased sensitisation to cocaine self administration

Selective reduced glutamate receptor subunit, and enkephalin response to cocaine, no effect on neuropeptide or dopamine receptor response

Decreased cocaine self administration

Decreased cocaine induced CPP $\quad 150$

Increased cocaine sensitisation

Synergistic actions on restoration of

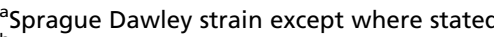


minimize variance. Yet sex differences in addiction are clear and the extensive evidence has been reviewed in human subjects and in experimental animals. Thus, women are more susceptible to addiction and are at greater risk of relapse than men $(154,155)$, and female rats are more susceptible than male rats. Substantial evidence links this to gonadal hormones (156).

There is nevertheless good reason to speculate that adrenocortical hormones are involved here as well. Both humans and rats have sex differences in adrenocortical function, and although different in nature, both may contribute to sex differences in addiction.

In humans, differences in circulating cortisol in males and females are marginal at most, though there may be differences in responsiveness to ACTH $(96,157,158)$. However, the major product of the gland is in fact DHEA, which is secreted not only as the free steroid, but also, and predominantly, as the sulphate, DHEAS. Plasma concentrations of DHEA and DHEAS in young adult men are about $12 \mathrm{nM}$ and $10 \mu \mathrm{M}$ respectively, compared with about $8 \mathrm{nM}$ and $<7 \mu \mathrm{M}$ in women, levels decrease with age but the sex differences are maintained $(96,159,160,161)$.

The point is that DHEA has been shown to be protective against drugs of addiction, as previously noted. Evidence from cerebrospinal fluid suggests that adrenal DHEA, and even DHEAS, may reach the brain in significant amounts (162), although how this relates to amounts synthesized within the brain cannot be assessed. Although no sex differences in cerebrospinal fluid were reported, it remains plausible that men receive more DHEA protection to addictive drugs than women $(154,162)$.

In rats, the situation is different, and there is no significant adrenal secretion of DHEA. However, there is a profound difference in secretion and circulating concentrations of corticosterone (the main glucocorticoid in the rat); adult female adrenals are nearly twice the size of males; and output of corticosterone is proportionately greater $(163,164,165,166)$. Although as noted earlier, DHEA is synthesized in the rat brain, there is no sex difference, and brain concentrations are similar in males and females (167). Accordingly, in the rat, it is plausible that heightened sensitivity to addictive drugs in females is associated with the higher circulating levels of corticosterone.

\section{The adrenal, addiction and the clock}

If it is the adrenal gland itself that is critical for HPAmodulated addictive processes, then other factors that are instrumental in generating adrenocortical responses may be expected to interact with addiction. Of the physiological stimuli that stimulate the adrenal cortex, stress is the most prominent and relevant. However, an equally potent regulator of the adrenal cortex is the clock.

That stress, however defined, facilitates addiction in both patients and animal models is well understood $(168,169,170,171,172)$. It is deeply interesting to note that clock time too has its effect on addictive craving and behaviours, although this literature generally has little reference to the HPA, but has been focused on the pineal and melatonin in the brain of male mice (173), or, primarily, on clock genes. Periodicity in PER1 and cocaine sensitivity are associated in male rats and mice of various strains (174), drug reinstatement can be suppressed by photoperiod in male rats (175), and clock gene variants are associated with cocaine sensitization in Drosophila (176) as with addiction in mice (sex not given) (177) and in humans, according to some authors $(178,179,180,181)$ but not all (182). In men, alcohol consumption over a 26-hour period affected neither melatonin nor the cortisol secretory diurnal variation $(183,184)$.

\section{Autonomy of the adrenal}

One feature of adrenocortical function that is hardly considered, in relation to addiction or anything else, is that mechanisms exist whereby the secretion of glucocorticoid appears to be regulated in part by local stimuli. $\mathrm{CRH}$ is notable among these. The relationship between the functions of hypothalamic CRH and CRH formed locally in the adrenal is currently obscure. That the adrenal gland of various species may secrete $\mathrm{CRH}$ from the medulla in response to splanchnic nerve stimulation has been shown, as has the direct stimulatory effect of CRH on corticosteroid secretion $(185,186,187,188)$. How does adrenal CRH vary with addiction? This is a topic for the future.

\section{Conclusion}

There is a clear pattern in the relationship of HPA activation to the development of addictive behaviours in response to quite different drugs. What is it they all have in common? Is there a unifying pathway that in so many cases leads to what may sometimes appear to be an addiction to the adrenal cortex and the secretion of glucocorticoids?

One point is becoming clear: $\mathrm{CRH}$ and POMC at different brain sites have clear functional links with the classical HPA (Fig. 1), and together, they may play similar roles in the adaptation that underlies addictive behaviour. They may be considered in the context of addiction as an expanded HPA, of which the terminal, and crucial, component is the adrenal cortex itself.

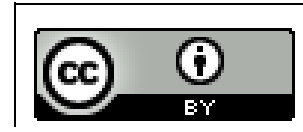

This work is licensed under a Creative Commons Attribution 3.0 Unported License. 
The evidence for the key importance of the adrenal cortex and glucocorticoids in behaviour and symptoms in drug withdrawal and reinstatement seems conclusive. Therapeutic control of glucocorticoid secretion or inhibition of glucocorticoid action at its receptor may be important future developments $(148,189)$ in what otherwise is a bleak therapeutic landscape $(48,189,190,191)$.

\section{Declaration of interest}

The authors declare that there is no conflict of interest that could be perceived as prejudicing the impartiality of the review.

\section{Funding}

This research did not receive any specific grant from any funding agency in the public, commercial or not-for-profit sector.

\section{References}

1 Lewis JT. Sensibility to intoxication in albino rats after double adrenalectomy. American Journal of Physiology 192364 506-511.

2 Mackay EM \& Mackay LL. Susceptibility of adrenalectomized rats to intoxication. Journal of Pharmacology and Experimental Therapeutics 192935 67-74

3 Mackay EM. The relation of acquired morphine tolerance to the adrenal cortex. Journal of Pharmacology and Experimental Therapeutics 193143 51-60.

4 Sung CY, Way EL \& Scott KG. Studies on the relationship of metabolic fate and hormonal effects of D,L-methadone to the development of drug tolerance. Journal of Pharmacology and Experimental Therapeutics 1953107 12-23.

5 Boswell WH. Narcotic addiction. Management of withdrawal symptoms with cortisone. United States Armed Forces Medical Journal 19512 1347-1351.

6 Lovell HW \& Tintera JW. Hypoadrenocorticism in alcoholism and drug addiction. Geriatrics 19516 1-11.

7 Fraser HF \& Isbell H. Failure of cortisone and ACTH in treatment of the morphine abstinence syndrome. Annals of Internal Medicine 195338 234-238. (doi:10.7326/0003-4819-38-2-234)

8 Altman LC, Hill JS, Hairfield WM \& Mullarkey MF. Effects of corticosteroids on eosinophil chemotaxis and adherence. Journal of Clinical Investigation 198167 28-36. (doi:10.1172/JCI110024)

9 Fraser HF. Tolerance to and physical dependence on opiates, barbiturates, and alcohol. Annual Review of Medicine 19578 427-440. (doi:10.1146/annurev.me.08.020157.002235)

10 Eisenman AJ, Fraser HF, Sloan J \& Isbell H. Urinary 17-ketosteroid excretion during a cycle of addiction to morphine. Journal of Pharmacology and Experimental Therapeutics 1958124 305-311.

11 Eisenman AJ, Fraser HF \& Brooks JW. Urinary excretion and plasma levels of 17-hydroxycorticosteroids during a cycle of addiction to morphine. Journal of Pharmacology and Experimental Therapeutics 1961 132 226-231.

12 Hochberg Z, Pacak K \& Chrousos GP. Endocrine withdrawal syndromes. Endocrine Reviews 200324 523-538. (doi:10.1210/er.2001-0014)

13 Lloyd RB \& Nemeroff CB. The role of corticotropin-releasing hormone in the pathophysiology of depression: therapeutic implications. Current Topics in Medicinal Chemistry 201111 609-617. (doi:10.2174/ 1568026611109060609)

14 Orth DN. Corticotropin-releasing hormone in humans. Endocrine Reviews 199213 164-191.
15 Chen R, Lewis KA, Perrin MH \& Vale WW. Expression cloning of a human corticotropin-releasing-factor receptor. PNAS 199390 8967-8971. (doi:10.1073/pnas.90.19.8967)

16 Vita N, Laurent P, Lefort S, Chalon P, Lelias JM, Kaghad M, Le Fur G, Caput D \& Ferrara P. Primary structure and functional expression of mouse pituitary and human brain corticotrophin releasing factor receptors. FEBS Letters 1993335 1-5. (doi:10.1016/0014-5793(93)80427-V)

17 Mitchell AJ. The role of corticotropin releasing factor in depressive illness: a critical review. Neuroscience and Biobehavioral Reviews 199822 635-651. (doi:10.1016/S0149-7634(97)00059-6)

18 Sarnyai Z, Shaham Y \& Heinrichs SC. The role of corticotropin-releasing factor in drug addiction. Pharmacological Reviews 200153 209-243.

19 Koob GF. Brain stress systems in the amygdala and addiction. Brain Research 20091293 61-75. (doi:10.1016/j.brainres.2009.03.038)

20 Aguilera G \& Liu Y. The molecular physiology of CRH neurons. Frontiers in Neuroendocrinology 201233 67-84. (doi:10.1016/j.yfrne. 2011.08.002)

21 Spina M, Merlo-Pich E, Chan RK, Basso AM, Rivier J, Vale W \& Koob GF. Appetite-suppressing effects of urocortin, a CRF-related neuropeptide. Science 1996273 1561-1564. (doi:10.1126/science.273.5281.1561)

22 Pelleymounter MA, Joppa M, Carmouche M, Cullen MJ, Brown B, Murphy B, Grigoriadis DE, Ling N \& Foster AC. Role of corticotropinreleasing factor (CRF) receptors in the anorexic syndrome induced by CRF. Journal of Pharmacology and Experimental Therapeutics 2000293 799-806.

23 Ho SP, Takahashi LK, Livanov V, Spencer K, Lesher T, Maciag C, Smith MA, Rohrbach KW, Hartig PR \& Arneric SP. Attenuation of fear conditioning by antisense inhibition of brain corticotropin releasing factor-2 receptor. Brain Research. Molecular Brain Research 200189 29-40. (doi:10.1016/S0169-328X(01)00050-X)

24 Takahashi LK, Ho SP, Livanov V, Graciani N \& Arneric SP. Antagonism of CRF(2) receptors produces anxiolytic behavior in animal models of anxiety. Brain Research 2001902 135-142. (doi:10.1016/S00068993(01)02405-2)

25 Koob GF. The role of CRF and CRF-related peptides in the dark side of addiction. Brain Research 20101314 3-14. (doi:10.1016/j.brainres. 2009.11.008)

26 Goeders NE. A neuroendocrine role in cocaine reinforcement. Psychoneuroendocrinology 199722 237-259. (doi:10.1016/S03064530(97)00027-9)

27 Goeders NE. The HPA axis and cocaine reinforcement. Psychoneuroendocrinology 200227 13-33. (doi:10.1016/S0306-4530(01)00034-8)

28 Mantsch JR, Cullinan WE, Tang LC, Baker DA, Katz ES, Hoks MA \& Ziegler DR. Daily cocaine self-administration under long-access conditions augments restraint-induced increases in plasma corticosterone and impairs glucocorticoid receptor-mediated negative feedback in rats. Brain Research 20071167 101-111. (doi:10.1016/ j.brainres.2007.05.080)

29 Mantsch JR, Taves S, Khan T, Katz ES, Sajan T, Tang LC, Cullinan WE \& Ziegler DR. Restraint-induced corticosterone secretion and hypothalamic CRH mRNA expression are augmented during acute withdrawal from chronic cocaine administration. Neuroscience Letters 2007415 269-273. (doi:10.1016/j.neulet.2007.01.036)

30 Shaham Y, Funk D, Erb S, Brown TJ, Walker CD \& Stewart J. Corticotropin-releasing factor, but not corticosterone, is involved in stress-induced relapse to heroin-seeking in rats. Journal of Neuroscience 199717 2605-2614.

31 Le AD, Harding S, Juzytsch W, Watchus J, Shalev U \& Shaham Y. The role of corticotrophin-releasing factor in stress-induced relapse to alcohol-seeking behavior in rats. Psychopharmacology $2000 \mathbf{1 5 0}$ 317-324. (doi:10.1007/s002130000411)

32 O'Callaghan MJ, Croft AP, Jacquot C \& Little HJ. The hypothalamopituitary-adrenal axis and alcohol preference. Brain Research Bulletin 2005 68 171-178. (doi:10.1016/j.brainresbull.2005.08.006)

33 Graf EN, Hoks MA, Baumgardner J, Sierra J, Vranjkovic O, Bohr C, Baker DA \& Mantsch JR. Adrenal activity during repeated long-access

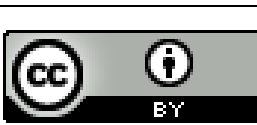


cocaine self-administration is required for later CRF-Induced and CRF-dependent stressor-induced reinstatement in rats. Neuropsychopharmacology 201136 1444-1454. (doi:10.1038/npp.2011.28)

34 Enoch MA, Shen PH, Ducci F, Yuan Q, Liu J, White KV, Albaugh B, Hodgkinson CA \& Goldman D. Common genetic origins for EEG, alcoholism and anxiety: the role of CRH-BP. PLOS ONE 20083 e3620. (doi:10.1371/journal.pone.0003620)

35 Ray LA. Stress-induced and cue-induced craving for alcohol in heavy drinkers: preliminary evidence of genetic moderation by the OPRM1 and CRH-BP genes. Alcoholism, Clinical and Experimental Research 2011 35 166-174. (doi:10.1111/j.1530-0277.2010.01333.x)

36 Zhou Y, Franck J, Spangler R, Maggos CE, Ho A \& Kreek MJ. Reduced hypothalamic POMC and anterior pituitary CRF1 receptor mRNA levels after acute, but not chronic, daily "binge" intragastric alcohol administration. Alcoholism, Clinical and Experimental Research 200024 1575-1582.

37 Richardson HN, Lee SY, O’Dell LE, Koob GF \& Rivier CL. Alcohol self-administration acutely stimulates the hypothalamic-pituitaryadrenal axis, but alcohol dependence leads to a dampened neuroendocrine state. European Journal of Neuroscience 200828 1641-1653. (doi:10.1111/j.1460-9568.2008.06455.x)

38 Lee B, Tiefenbacher S, Platt DM \& Spealman RD. Role of the hypothalamic-pituitary-adrenal axis in reinstatement of cocaineseeking behavior in squirrel monkeys. Psychopharmacology 2003168 177-183. (doi:10.1007/s00213-003-1391-4)

39 Buckingham JC \& Cooper TA. Pharmacological characterization of opioid receptors influencing the secretion of corticotrophin releasing factor in the rat. Neuroendocrinology 198644 36-40. (doi:10.1159/ 000124618)

40 Tsagarakis S, Rees LH, Besser M \& Grossman A. Opiate receptor subtype regulation of CRF-41 release from rat hypothalamus in vitro. Neuroendocrinology $1990 \mathbf{5 1}$ 599-605. (doi:10.1159/000125397)

41 Kreek MJ, Borg L, Zhou Y \& Schluger J. Relationships between endocrine functions and substance abuse syndromes: heroin and related short-acting opiates in addiction contrasted with methadone and other long acting agonists used in pharmacotherapy of addiction. In Hormones, Brain, and Behaviour, 2nd edn, pp 781-829. Eds DW Pfaff, AP Arnold, AM Etgen, RT Rubin \& SE Fahrbach. San Diego, CA: Elsevier, 2002.

42 Buckingham JC \& Cooper TA. Differences in hypothalamo-pituitaryadrenocortical activity in the rat after acute and prolonged treatment with morphine. Neuroendocrinology 198438 411-417. (doi:10.1159/ 000123927)

43 Zhou Y, Spangler R, Maggos CE, Wang XM, Han JS, Ho A \& Kreek MJ. Hypothalamic-pituitary-adrenal activity and pro-opiomelanocortin mRNA levels in the hypothalamus and pituitary of the rat are differentially modulated by acute intermittent morphine with or without water restriction stress. Journal of Endocrinology 1999163 261-267. (doi:10.1677/joe.0.1630261)

44 Kupferschmidt DA, Newman AE, Boonstra R \& Erb S. Antagonism of cannabinoid 1 receptors reverses the anxiety-like behavior induced by central injections of corticotropin-releasing factor and cocaine withdrawal. Neuroscience 2012204 125-133. (doi:10.1016/ j.neuroscience.2011.07.022)

45 Buckingham JC \& Cooper TA. Effects of naloxone on hypothalamopituitary-adrenocortical activity in the rat. Neuroendocrinology 198642 421-426. (doi:10.1159/000124481)

46 Tsagarakis S, Navarra P, Rees LH, Besser M, Grossman A \& Navara P. Morphine directly modulates the release of stimulated corticotrophinreleasing factor-41 from rat hypothalamus in vitro. Endocrinology 1989 124 2330-2335. (doi:10.1210/endo-124-5-2330)

47 Oswald LM \& Wand GS. Opioids and alcoholism. Physiology \& Behavior 200481 339-358. (doi:10.1016/j.physbeh.2004.02.008)

48 Heilig M, Goldman D, Berrettini W \& O'Brien CP. Pharmacogenetic approaches to the treatment of alcohol addiction. Nature Reviews. Neuroscience 201112 670-684. (doi:10.1038/nrn3110)
49 Armario A. Activation of the hypothalamic-pituitary-adrenal axis by addictive drugs: different pathways, common outcome. Trends in Pharmacological Sciences 201031 318-325. (doi:10.1016/j.tips.2010.04.005)

50 Zhang X, Sliwowska JH \& Weinberg J. Prenatal alcohol exposure and fetal programming: effects on neuroendocrine and immune function. Experimental Biology and Medicine 2005230 376-388.

51 Allen CD, Rivier CL \& Lee SY. Adolescent alcohol exposure alters the central brain circuits known to regulate the stress response. Neuroscience 2011182 162-168. (doi:10.1016/j.neuroscience. 2011.03.003)

52 Cippitelli A, Damadzic R, Singley E, Thorsell A, Ciccocioppo R, Eskay RL \& Heilig M. Pharmacological blockade of corticotropinreleasing hormone receptor 1 (CRH1R) reduces voluntary consumption of high alcohol concentrations in non-dependent Wistar rats. Pharmacology, Biochemistry and Behavior 2012100 522-529. (doi:10.1016/j.pbb.2011.10.016)

53 Pastor R, McKinnon CS, Scibelli AC, Burkhart-Kasch S, Reed C, Ryabinin AE, Coste SC, Stenzel-Poore MP \& Phillips TJ. Corticotropinreleasing factor-1 receptor involvement in behavioral neuroadaptation to ethanol: a urocortin1-independent mechanism. PNAS 2008 105 9070-9075. (doi:10.1073/pnas.0710181105)

54 Giardino WJ, Pastor R, Anacker AM, Spangler E, Cote DM, Li J, Stenzel-Poore MP, Phillips TJ \& Ryabinin AE. Dissection of corticotropin-releasing factor system involvement in locomotor sensitivity to methamphetamine. Genes, Brain and Behavior 201210 78-89. (doi:10.1111/j.1601-183X.2010.00641.x)

55 Raffin-Sanson ML, de Keyzer Y \& Bertagna X. Proopiomelanocortin, a polypeptide precursor with multiple functions: from physiology to pathological conditions. European Journal of Endocrinology 2003149 79-90. (doi:10.1530/eje.0.1490079)

56 Cone RD. Anatomy and regulation of the central melanocortin system. Nature Neuroscience 20058 571-578. (doi:10.1038/nn1455)

57 King CM \& Hentges ST. Relative number and distribution of murine hypothalamic proopiomelanocortin neurons innervating distinct target sites. PLOS ONE 20116 e25864. (doi:10.1371/journal.pone. 0025864)

58 Starowicz K, Bilecki W, Sieja A, Przewlocka B \& Przewlocki R. Melanocortin 4 receptor is expressed in the dorsal root ganglions and down-regulated in neuropathic rats. Neuroscience Letters 2004358 79-82. (doi:10.1016/j.neulet.2003.12.096)

59 Bergland R, Blume H, Hamilton A, Monica P \& Paterson R. Adrenocorticotropic hormone may be transported directly from the pituitary to the brain. Science $1980210541-543$. (doi:10.1126/science. 6252607)

60 Kapcala LP, Lechan R \& Reichlin S. Origin of immunoreactive ACTH in brain sites outside the ventral hypothalamus. Neuroendocrinology 1983 37 440-445. (doi:10.1159/000123590)

61 Carr DB, Jones KJ, Bergland RM, Hamilton A, Kasting NW, Fisher JE \& Martin JB. Causal links between plasma and CSF endorphin levels in stress: vector-ARMA analysis. Peptides 19856 (Suppl 1) 5-10. (doi:10.1016/0196-9781(85)90004-X)

62 Twyman RM. Hormonal signalling to the brain for the control of feeding/energy balance. In Encyclopedia of Neuroscience, pp 1201-1206. Ed LR Squire. Oxford: Academic Press, 2009.

63 Marcinkiewicz M, Day R, Seidah NG \& Chretien M. Ontogeny of the prohormone convertases PC1 and PC2 in the mouse hypophysis and their colocalization with corticotropin and $\alpha$-melanotropin. PNAS 199390 4922-4926. (doi:10.1073/pnas.90.11.4922)

64 Allen RG, Peng B, Pellegrino MJ, Miller ED, Grandy DK, Lundblad JR, Washburn CL \& Pintar JE. Altered processing of pro-orphanin $\mathrm{FQ} /$ nociceptin and pro-opiomelanocortin-derived peptides in the brains of mice expressing defective prohormone convertase 2 . Journal of Neuroscience 200121 5864-5870.

65 Grill HJ. Distributed neural control of energy balance: contributions from hindbrain and hypothalamus. Obesity 200614 (Suppl 5) 216S-221S. (doi:10.1038/oby.2006.312)

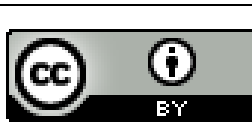


66 Millington GW. The role of proopiomelanocortin (POMC) neurones in feeding behaviour. Nutrition and Metabolism 2007418. (doi:10.1186/1743-7075-4-18)

67 Berglund ED, Vianna CR, Donato J Jr, Kim MH, Chuang JC, Lee CE, Lauzon DA, Lin P, Brule LJ, Scott MM et al. Direct leptin action on POMC neurons regulates glucose homeostasis and hepatic insulin sensitivity in mice. Journal of Clinical Investigation 2012122 1000-1009. (doi:10.1172/JCI59816)

68 Roubos EW, Dahmen M, Kozicz T \& Xu L. Leptin and the hypothalamo-pituitary-adrenal stress axis. General and Comparative Endocrinology 2012177 28-36. (doi:10.1016/j.ygcen.2012.01.009)

69 Alvaro JD, Tatro JB \& Duman RS. Melanocortins and opiate addiction. Life Sciences 199761 1-9. (doi:10.1016/S0024-3205(97)00029-5)

70 Starowicz K, Sieja A, Bilecki W, Obara I \& Przewlocka B. The effect of morphine on MC4 and CRF receptor mRNAs in the rat amygdala and attenuation of tolerance after their blockade. Brain Research 2003990 113-119. (doi:10.1016/S0006-8993(03)03444-9)

71 Starowicz K, Obara I, Przewlocki R \& Przewlocka B. Inhibition of morphine tolerance by spinal melanocortin receptor blockade. Pain 2005117 401-411. (doi:10.1016/j.pain.2005.07.003)

72 Ercil NE, Galici R \& Kesterson RA. HS014, a selective melanocortin-4 (MC4) receptor antagonist, modulates the behavioral effects of morphine in micemodulates the behavioral effects of morphine in mice. Psychopharmacology 2005180 279-285. (doi:10.1007/ s00213-005-2166-x)

73 Hsu R, Taylor JR, Newton SS, Alvaro JD, Haile C, Han G, Hruby VJ, Nestler EJ \& Duman RS. Blockade of melanocortin transmission inhibits cocaine reward. European Journal of Neuroscience 200521 2233-2242. (doi:10.1111/j.1460-9568.2005.04038.x)

74 Kokare DM, Singru PS, Dandekar MP, Chopde CT \& Subhedar NK. Involvement of $\alpha$-melanocyte stimulating hormone ( $\alpha$-MSH) in differential ethanol exposure and withdrawal related depression in rat: neuroanatomical-behavioral correlates. Brain Research 20081216 53-67. (doi:10.1016/j.brainres.2008.03.064)

75 Jessop DS. Review: central non-glucocorticoid inhibitors of the hypothalamo-pituitary-adrenal axis. Journal of Endocrinology 1999 160 169-180. (doi:10.1677/joe.0.1600169)

76 Tronche F, Kellendonk C, Kretz O, Gass P, Anlag K, Orban PC, Bock R, Klein R \& Schutz G. Disruption of the glucocorticoid receptor gene in the nervous system results in reduced anxiety. Nature Genetics 199923 99-103. (doi:10.1038/12703)

77 Arnett MG, Kolber BJ, Boyle MP \& Muglia LJ. Behavioral insights from mouse models of forebrain- and amygdala-specific glucocorticoid receptor genetic disruption. Molecular and Cellular Endocrinology 2011 336 2-5. (doi:10.1016/j.mce.2010.11.011)

78 Liu J, Garza JC, Truong HV, Henschel J, Zhang W \& Lu XY. The melanocortinergic pathway is rapidly recruited by emotional stress and contributes to stress-induced anorexia and anxiety-like behavior. Endocrinology 2007148 5531-5540. (doi:10.1210/en.2007-0745)

79 Kawashima S, Sakihara S, Kageyama K, Nigawara T \& Suda T. Corticotropin-releasing factor (CRF) is involved in the acute anorexic effect of $\alpha$-melanocyte-stimulating hormone: a study using CRF-deficient mice. Peptides 200829 2169-2174. (doi:10.1016/ j.peptides.2008.09.010)

80 Smart JL, Tolle V, Otero-Corchon V \& Low MJ. Central dysregulation of the hypothalamic-pituitary-adrenal axis in neuron-specific proopiomelanocortin-deficient mice. Endocrinology 2007148 647-659. (doi:10.1210/en.2006-0990)

81 Fekete C, Legradi G, Mihaly E, Huang QH, Tatro JB, Rand WM, Emerson CH \& Lechan RM. $\alpha$-Melanocyte-stimulating hormone is contained in nerve terminals innervating thyrotropin-releasing hormone-synthesizing neurons in the hypothalamic paraventricular nucleus and prevents fasting-induced suppression of prothyrotropinreleasing hormone gene expression. Journal of Neuroscience $20002 \mathbf{2 0}$ 1550-1558.
$82 \mathrm{Lu} \mathrm{XY,} \mathrm{Barsh} \mathrm{GS,} \mathrm{Akil} \mathrm{H} \mathrm{\&} \mathrm{Watson} \mathrm{SJ.} \mathrm{Interaction} \mathrm{between}$ $\alpha$-melanocyte-stimulating hormone and corticotropin-releasing hormone in the regulation of feeding and hypothalamo-pituitaryadrenal responses. Journal of Neuroscience 200323 7863-7872.

83 Cragnolini AB, Perello M, Schioth HB \& Scimonelli TN. $\alpha$-MSH and $\gamma$-MSH inhibit IL-1 $\beta$ induced activation of the hypothalamicpituitary-adrenal axis through central melanocortin receptors. Regulatory Peptides 2004122 185-190. (doi:10.1016/j.regpep.2004.06.011)

84 Sebag JA \& Hinkle PM. Regulation of endogenous melanocortin-4 receptor expression and signaling by glucocorticoids. Endocrinology 2006147 5948-5955. (doi:10.1210/en.2006-0984)

85 Fester L, Prange-Kiel J, Jarry H \& Rune GM. Estrogen synthesis in the hippocampus. Cell and Tissue Research 2011345 285-294. (doi:10.1007/s00441-011-1221-7)

86 Prange-Kiel J \& Rune GM. Direct and indirect effects of estrogen on rat hippocampus. Neuroscience 2006138 765-772. (doi:10.1016/ j.neuroscience.2005.05.061)

87 Peri A, Danza G, Benvenuti S, Luciani P, Deledda C, Rosati F, Cellai I \& Serio M. New insights on the neuroprotective role of sterols and sex steroids: the seladin-1/DHCR24 paradigm. Frontiers in Neuroendocrinology 200930 119-129. (doi:10.1016/j.yfrne.2009.03.006)

88 Saldanha CJ, Duncan KA \& Walters BJ. Neuroprotective actions of brain aromatase. Frontiers in Neuroendocrinology 200930 106-118. (doi:10.1016/j.yfrne.2009.04.016)

89 Micevych P, Soma KK \& Sinchak K. Neuroprogesterone: key to estrogen positive feedback? Brain Research Reviews 200857 470-480. (doi:10.1016/j.brainresrev.2007.06.009)

90 Gillies GE \& McArthur S. Estrogen actions in the brain and the basis for differential action in men and women: a case for sex-specific medicines. Pharmacological Reviews 201062 155-198. (doi:10.1124/ pr.109.002071)

91 Gillies GE \& McArthur S. Independent influences of sex steroids of systemic and central origin in a rat model of Parkinson's disease: a contribution to sex-specific neuroprotection by estrogens. Hormones and Behavior 201057 23-34. (doi:10.1016/j.yhbeh.2009.06.002)

92 Fester L, Prange-Kiel J, Zhou L, Blittersdorf BV, Bohm J, Jarry H, Schumacher M \& Rune GM. Estrogen-regulated synaptogenesis in the hippocampus: sexual dimorphism in vivo but not in vitro. Journal of Steroid Biochemistry and Molecular Biology $201213124-29$. (doi:10.1016/j.jsbmb.2011.11.010)

93 Mermelstein PG \& Micevych PE. Nervous system physiology regulated by membrane estrogen receptors. Reviews in the Neurosciences 200819 413-424. (doi:10.1515/REVNEURO.2008.19.6.413)

94 Micevych PE \& Mermelstein PG. Membrane estrogen receptors acting through metabotropic glutamate receptors: an emerging mechanism of estrogen action in brain. Molecular Neurobiology 200838 66-77. (doi:10.1007/s12035-008-8034-z)

95 Baulieu EE, Corpechot C, Dray F, Emiliozzi R, Lebeau MC, Mauvais Jarvis P \& Robel P. An adrenal-secreted "androgen": dehydroisoandrosterone sulfate. Its metabolism and a tentative generalization on the metabolism of other steroid conjugates in man. Recent Progress in Hormone Research 196521 411-500.

96 Vinson GP, Whitehouse BJ \& Hinson JP. In The Adrenal Cortex, ch 3, pp 65-139. Englewood Heights, NJ, USA: Prentice-Hall, 1992.

97 Baulieu EE. Neurosteroids: a novel function of the brain. Psychoneuroendocrinology 199823 963-987. (doi:10.1016/S0306-4530(98)00071-7)

98 Mellon SH. Neurosteroid regulation of central nervous system development. Pharmacology \& Therapeutics 2007116 107-124. (doi:10.1016/j.pharmthera.2007.04.011)

99 Baulieu EE \& Robel P. Dehydroepiandrosterone (DHEA) and dehydroepiandrosterone sulfate (DHEAS) as neuroactive neurosteroids. PNAS 199895 4089-4091. (doi:10.1073/pnas.95.8.4089)

100 Romieu P, Martin-Fardon R, Bowen WD \& Maurice T. Sigma 1 receptor-related neuroactive steroids modulate cocaine-induced reward. Journal of Neuroscience 200323 3572-3576.

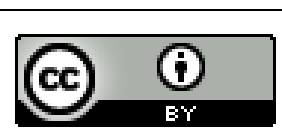

This work is licensed under a Creative Commons Attribution 3.0 Unported License. 
101 Maayan R, Lotan S, Doron R, Shabat-Simon M, Gispan-Herman I, Weizman A \& Yadid G. Dehydroepiandrosterone (DHEA) attenuates cocaine-seeking behavior in the self-administration model in rats. European Neuropsychopharmacology 200616 329-339. (doi:10.1016/ j.euroneuro.2005.10.002)

102 Wilkins JN, Majewska MD, Van Gorp W, Li SH, Hinken C, Plotkin D \& Setoda D. DHEAS and POMS measures identify cocaine dependence treatment outcome. Psychoneuroendocrinology 200530 18-28. (doi:10.1016/j.psyneuen.2004.04.006)

103 Doron R, Fridman L, Gispan-Herman I, Maayan R, Weizman A \& Yadid G. DHEA, a neurosteroid, decreases cocaine self-administration and reinstatement of cocaine-seeking behavior in rats. Neuropsychopharmacology 200631 2231-2236.

104 Maayan R, Touati-Werner D, Shamir D, Yadid G, Friedman A, Eisner D, Weizman A \& Herman I. The effect of DHEA complementary treatment on heroin addicts participating in a rehabilitation program: a preliminary study. European Neuropsychopharmacology 200818 406-413. (doi:10.1016/j.euroneuro.2007.12.003)

105 Yadid G, Sudai E, Maayan R, Gispan I \& Weizman A. The role of dehydroepiandrosterone (DHEA) in drug-seeking behavior. Neuroscience and Biobehavioral Reviews 201035 303-314. (doi:10.1016/ j.neubiorev.2010.03.003)

106 Boyd KN, Kumar S, O’Buckley TK, Porcu P \& Morrow AL. Ethanol induction of steroidogenesis in rat adrenal and brain is dependent upon pituitary ACTH release and de novo adrenal StAR synthesis. Journal of Neurochemistry 2010112 784-796. (doi:10.1111/ j.1471-4159.2009.06509.x)

107 Vinson GP. The mislabelling of deoxycorticosterone: making sense of corticosteroid structure and function. Journal of Endocrinology 2011 211 3-16. (doi:10.1530/JOE-11-0178)

108 Barbaccia ML, Affricano D, Trabucchi M, Purdy RH, Colombo G, Agabio R \& Gessa GL. Ethanol markedly increases "GABAergic" neurosteroids in alcohol-preferring rats. European Journal of Pharmacology 1999384 R1-R2. (doi:10.1016/S0014-2999(99)00678-0)

109 Palamarchouk V, Smagin G \& Goeders NE. Self-administered and passive cocaine infusions produce different effects on corticosterone concentrations in the medial prefrontal cortex (MPC) of rats. Pharmacology, Biochemistry and Behavior 200994 163-168. (doi:10.1016/j.pbb.2009.08.003)

110 Gomez-Sanchez CE, Zhou MY, Cozza EN, Morita H, Foecking MF \& Gomez-Sanchez EP. Aldosterone biosynthesis in the rat brain. Endocrinology 1997138 3369-3373. (doi:10.1210/en.138.8.3369)

111 Higo S, Hojo Y, Ishii H, Komatsuzaki Y, Ooishi Y, Murakami G, Mukai H, Yamazaki T, Nakahara D, Barron A et al. Endogenous synthesis of corticosteroids in the hippocampus. PLOS ONE 20116 e21631. (doi:10.1371/journal.pone.0021631)

112 Taves MD, Gomez-Sanchez CE \& Soma KK. Extra-adrenal glucocorticoids and mineralocorticoids: evidence for local synthesis, regulation, and function. American Journal of Physiology. Endocrinology and Metabolism 2011301 E11-E24. (doi:10.1152/ajpendo.00100.2011)

113 Davies E \& MacKenzie SM. Extra-adrenal production of corticosteroids. Clinical and Experimental Pharmacology \& Physiology 200330 437-445. (doi:10.1046/j.1440-1681.2003.03867.x)

114 Herbert J, Goodyer IM, Grossman AB, Hastings MH, de Kloet ER, Lightman SL, Lupien SJ, Roozendaal B \& Seckl JR. Do corticosteroids damage the brain? Journal of Neuroendocrinology 200618 393-411. (doi:10.1111/j.1365-2826.2006.01429.x)

115 Ingle D. The biologic properties of cortisone: a review. Journal of Clinical Endocrinology 195010 1312-1354. (doi:10.1210/jcem-1010-1312)

116 Bolanos SH, Khan DA, Hanczyc M, Bauer MS, Dhanani N \& Brown ES. Assessment of mood states in patients receiving long-term corticosteroid therapy and in controls with patient-rated and clinician-rated scales. Annals of Allergy, Asthma \& Immunology 200492 500-505. (doi:10.1016/S1081-1206(10)61756-5)
117 Klein JF. Adverse psychiatric effects of systemic glucocorticoid therapy. American Family Physician 199246 1469-1474.

118 Brown ES \& Suppes T. Mood symptoms during corticosteroid therapy: a review. Harvard Review of Psychiatry 19985 239-246. (doi:10.3109/ 10673229809000307)

119 Sirois F. Steroid psychosis: a review. General Hospital Psychiatry 200325 27-33. (doi:10.1016/S0163-8343(02)00241-4)

120 Warrington TP \& Bostwick JM. Psychiatric adverse effects of corticosteroids. Mayo Clinic Proceedings 200681 1361-1367. (doi:10.4065/81.10.1361)

121 Michael RP \& Gibbons JL. Interrelationships between the endocrine system neuropsychiatry. International Review of Neurobiology 19635 243-302.

122 Van Craenenbroeck K, De Bosscher K, Vanden Berghe W, Vanhoenacker P \& Haegeman G. Role of glucocorticoids in dopaminerelated neuropsychiatric disorders. Molecular and Cellular Endocrinology 2005245 10-22. (doi:10.1016/j.mce.2005.10.007)

123 Montaron MF, Piazza PV, Aurousseau C, Urani A, Le Moal M \& Abrous DN. Implication of corticosteroid receptors in the regulation of hippocampal structural plasticity. European Journal of Neuroscience 200318 3105-3111. (doi:10.1111/j.1460-9568.2003.03048.x)

124 Zunszain PA, Anacker C, Cattaneo A, Carvalho LA \& Pariante CM. Glucocorticoids, cytokines and brain abnormalities in depression. Progress in Neuro-Psychopharmacology \& Biological Psychiatry 201135 722-729. (doi:10.1016/j.pnpbp.2010.04.011)

125 Anacker C, Zunszain PA, Carvalho LA \& Pariante CM. The glucocorticoid receptor: pivot of depression and of antidepressant treatment? Psychoneuroendocrinology 201136 415-425. (doi:10.1016/ j.psyneuen.2010.03.007)

126 Horstmann S \& Binder EB. Glucocorticoids as predictors of treatment response in depression. Harvard Review of Psychiatry 201119 125-143. (doi:10.3109/10673229.2011.586550)

127 Medh RD, Lay RH \& Schmidt TJ. Agonist-specific modulation of glucocorticoid receptor-mediated transcription by immunosuppressants. Molecular and Cellular Endocrinology 1998138 11-23. (doi:10.1016/S0303-7207(98)00055-0)

128 Pariante CM, Thomas SA, Lovestone S, Makoff A \& Kerwin RW. Do antidepressants regulate how cortisol affects the brain? Psychoneuroendocrinology 200429 423-447. (doi:10.1016/ j.psyneuen.2003.10.009)

129 Kelly M. Steroids: drugs of addiction to patient and doctor. Journal of Chronic Diseases 196417 461-464. (doi:10.1016/0021-9681(64)90106-7)

130 Kelly M. Steroids are drugs of addiction. Rheumatism 196521 50-54.

131 Morgan HG, Boulnois J \& Burns-Cox C. Addiction to prednisone. BMJ 19732 93-94. (doi:10.1136/bmj.2.5858.93)

132 Kligman AM \& Frosch PJ. Steroid addiction. International Journal of Dermatology 197918 23-31. (doi:10.1111/j.1365-4362.1979.tb01905.x)

133 Brown ES. Chemical dependence involving glucocorticoids. Annals of Clinical Psychiatry 19979 185-187. (doi:10.3109/10401239709 147796)

134 Anfinson TJ, Channappa C \& Vo HT. Drug dependence involving prednisone: two cases and a review of the literature. Psychopharmacology Bulletin 200841 154-163.

135 Mendelson JH, Sholar MB, Goletiani N, Siegel AJ \& Mello NK. Effects of low- and high-nicotine cigarette smoking on mood states and the HPA axis in men. Neuropsychopharmacology 200530 1751-1763. (doi:10.1038/sj.npp.1300753)

136 Fox HC, Jackson ED \& Sinha R. Elevated cortisol and learning and memory deficits in cocaine dependent individuals: relationship to relapse outcomes. Psychoneuroendocrinology 200934 1198-1207. (doi:10.1016/j.psyneuen.2009.03.007)

137 de Kloet ER, Oitzl MS \& Joels M. Stress and cognition: are corticosteroids good or bad guys? Trends in Neurosciences 199922 422-426. (doi:10.1016/S0166-2236(99)01438-1)

138 Hamidovic A, Childs E, Conrad M, King A \& de Wit H. Stress-induced changes in mood and cortisol release predict mood effects of

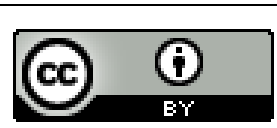

This work is licensed under a Creative Commons Attribution 3.0 Unported License. 
amphetamine. Drug and Alcohol Dependence 2010109 175-180. (doi:10.1016/j.drugalcdep.2009.12.029)

139 Deroche V, Piazza PV, Deminiere JM, Le Moal M \& Simon H. Rats orally self-administer corticosterone. Brain Research 1993622 315-320. (doi:10.1016/0006-8993(93)90837-D)

140 Piazza PV, Deroche V, Deminiere JM, Maccari S, Le Moal M \& Simon H. Corticosterone in the range of stress-induced levels possesses reinforcing properties: implications for sensation-seeking behaviors. PNAS 199390 11738-11742. (doi:10.1073/pnas.90.24.11738)

141 de Jong IE, Steenbergen PJ \& de Kloet ER. Behavioral sensitization to cocaine: cooperation between glucocorticoids and epinephrine. Psychopharmacology 2009204 693-703. (doi:10.1007/s00213-009-1498-3)

142 Roberts AJ, Lessov CN \& Phillips TJ. Critical role for glucocorticoid receptors in stress- and ethanol-induced locomotor sensitization. Journal of Pharmacology and Experimental Therapeutics 1995275 790-797.

143 Piazza PV, Marinelli M, Jodogne C, Deroche V, Rouge-Pont F, Maccari S, Le Moal M \& Simon H. Inhibition of corticosterone synthesis by metyrapone decreases cocaine-induced locomotion and relapse of cocaine self-administration. Brain Research $1994 \mathbf{6 5 8}$ 259-264. (doi:10.1016/S0006-8993(09)90034-8)

144 Mantsch JR, Saphier D \& Goeders NE. Corticosterone facilitates the acquisition of cocaine self-administration in rats: opposite effects of the type II glucocorticoid receptor agonist dexamethasone. Journal of Pharmacology and Experimental Therapeutics 1998287 72-80.

145 Piazza PV, Barrot M, Rouge-Pont F, Marinelli M, Maccari S, Abrous DN, Simon H \& Le Moal M. Suppression of glucocorticoid secretion and antipsychotic drugs have similar effects on the mesolimbic dopaminergic transmission. PNAS 199693 15445-15450. (doi:10.1073/ pnas.93.26.15445)

146 Danilczuk Z, Ossowska G, Wrobel A \& Lupina T. Glucocorticoids modulate behavioral effects induced by dopaminergic agonists in rats. Polish Journal of Pharmacology 200153 467-473.

147 Marinelli M, Aouizerate B, Barrot M, Le Moal M \& Piazza PV. Dopaminedependent responses to morphine depend on glucocorticoid receptors. PNAS 199895 7742-7747. (doi:10.1073/pnas.95.13.7742)

148 Deroche-Gamonet V, Sillaber I, Aouizerate B, Izawa R, Jaber M, Ghozland S, Kellendonk C, Le Moal M, Spanagel R, Schutz G et al. The glucocorticoid receptor as a potential target to reduce cocaine abuse. Journal of Neuroscience 200323 4785-4790.

149 Ambroggi F, Turiault M, Milet A, Deroche-Gamonet V, Parnaudeau S, Balado E, Barik J, van der Veen R, Maroteaux G, Lemberger T et al. Stress and addiction: glucocorticoid receptor in dopaminoceptive neurons facilitates cocaine seeking. Nature Neuroscience 200912 247-249. (doi:10.1038/nn.2282)

150 Barik J, Parnaudeau S, Saint Amaux AL, Guiard BP, Golib Dzib JF, Bocquet O, Bailly A, Benecke A \& Tronche F. Glucocorticoid receptors in dopaminoceptive neurons, key for cocaine, are dispensable for molecular and behavioral morphine responses. Biological Psychiatry 201068 231-239. (doi:10.1016/j.biopsych.2010.03.037)

151 Dong Z, Han H, Wang M, Xu L, Hao W \& Cao J. Morphine conditioned place preference depends on glucocorticoid receptors in both hippocampus and nucleus accumbens. Hippocampus $2006 \mathbf{1 6}$ 809-813. (doi:10.1002/hipo.20216)

152 Wei Q, Fentress HM, Hoversten MT, Zhang L, Hebda-Bauer EK, Watson SJ, Seasholtz AF \& Akil H. Early-life forebrain glucocorticoid receptor overexpression increases anxiety behavior and cocaine sensitization. Biological Psychiatry 201271 224-231. (doi:10.1016/ j.biopsych.2011.07.009)

153 Desrivieres S, Lourdusamy A, Muller C, Ducci F, Wong CP, Kaakinen M, Pouta A, Hartikainen AL, Isohanni M, Charoen P et al. Glucocorticoid receptor (NR3C1) gene polymorphisms and onset of alcohol abuse in adolescents. Addiction Biology 201116 510-513. (doi:10.1111/j.1369-1600.2010.00239.x)

154 Devaud LL, Alele P \& Ritu C. Sex differences in the central nervous system actions of ethanol. Critical Reviews in Neurobiology 200315 41-59. (doi:10.1615/CritRevNeurobiol.v15.i1.20)
155 Becker JB \& Hu M. Sex differences in drug abuse. Frontiers in Neuroendocrinology 200829 36-47. (doi:10.1016/j.yfrne.2007.07.003)

156 Festa ED, Russo SJ, Gazi FM, Niyomchai T, Kemen LM, Lin SN, Foltz R, Jenab S \& Quinones-Jenab V. Sex differences in cocaine-induced behavioral responses, pharmacokinetics, and monoamine levels. Neuropharmacology 200446 672-687. (doi:10.1016/j.neuropharm. 2003.11.017)

157 Weekes N, Lewis R, Patel F, Garrison-Jakel J, Berger DE \& Lupien SJ. Examination stress as an ecological inducer of cortisol and psychological responses to stress in undergraduate students. Stress 20069 199-206. (doi:10.1080/10253890601029751)

158 Keenan DM, Roelfsema F, Carroll BJ, Iranmanesh A \& Veldhuis JD. Sex defines the age dependence of endogenous ACTH-cortisol dose responsiveness. American Journal of Physiology. Regulatory, Integrative and Comparative Physiology 2009297 R515-R523. (doi:10.1152/ ajpregu.00200.2009)

159 Parker CR Jr \& Porter JC. Developmental changes in molecular forms of immunoreactive adrenocorticotropin in the anterior pituitary gland of humans. Endocrine Research 199925 397-410. (doi:10.1080/ 07435809909066156)

160 Rainey WE, Carr BR, Sasano H, Suzuki T \& Mason JI. Dissecting human adrenal androgen production. Trends in Endocrinology and Metabolism 200213 234-239. (doi:10.1016/S1043-2760(02)00609-4)

161 Muniyappa R, Wong KA, Baldwin HL, Sorkin JD, Johnson ML, Bhasin S, Harman SM \& Blackman MR. Dehydroepiandrosterone secretion in healthy older men and women: effects of testosterone and growth hormone administration in older men. Journal of Clinical Endocrinology and Metabolism 200691 4445-4452. (doi:10.1210/jc.2006-0867)

162 Guazzo EP, Kirkpatrick PJ, Goodyer IM, Shiers HM \& Herbert J. Cortisol, dehydroepiandrosterone (DHEA), and DHEA sulfate in the cerebrospinal fluid of man: relation to blood levels and the effects of age. Journal of Clinical Endocrinology and Metabolism $1996 \mathbf{8 1}$ 3951-3960. (doi:10.1210/jc.81.11.3951)

163 Jones IC. Role of the adrenal cortex in reproduction. British Medical Bulletin 195511 156-160.

164 Cortes JM, Peron FG \& Dorfman RI. Secretion of 18-hydroxydeoxycorticosterone by the rat adrenal gland. Endocrinology $1963 \mathbf{7 3}$ 713-720. (doi:10.1210/endo-73-6-713)

165 Critchlow V, Liebelt RA, Bar-Sela M, Mountcastle W \& Lipscomb HS. Sex difference in resting pituitary-adrenal function in the rat. American Journal of Physiology 1963205 807-815.

166 Malendowicz LK, Robba C \& Nussdorfer GG. Sex differences in adrenocortical structure and function. XXII. Light- and electronmicroscopic morphometric studies on the effects of gonadectomy and gonadal hormone replacement on the rat adrenal cortex. Cell and Tissue Research 1986244 141-145. (doi:10.1007/BF00218391)

167 Torres JM \& Ortega E. DHEA, PREG and their sulphate derivatives on plasma and brain after CRH and ACTH administration. Neurochemical Research 200328 1187-1191. (doi:10.1023/A:1024276328127)

168 Goeders NE. The impact of stress on addiction. European Neuropsychopharmacology 200313 435-441. (doi:10.1016/j.euroneuro.2003.08.004)

169 Uhart M \& Wand GS. Stress, alcohol and drug interaction: an update of human research. Addiction Biology 2009 14 43-64. (doi:10.1111/ j.1369-1600.2008.00131.x)

170 Kosten TR. Stress and addiction. American Journal of Psychiatry 2011 168 566-568. (doi:10.1176/appi.ajp.2011.11020180)

171 Logrip ML, Zorrilla EP \& Koob GF. Stress modulation of drug self-administration: implications for addiction comorbidity with post-traumatic stress disorder. Neuropharmacology $201162552-564$. (doi:10.1016/j.neuropharm.2011.07.007)

172 Schwabe L, Dickinson A \& Wolf OT. Stress, habits, and drug addiction: a psychoneuroendocrinological perspective. Experimental and Clinical Psychopharmacology 201119 53-63. (doi:10.1037/a0022212)

$173 \mathrm{Uz} \mathrm{T}$, Akhisaroglu M, Ahmed R \& Manev H. The pineal gland is critical for circadian Period1 expression in the striatum and for circadian

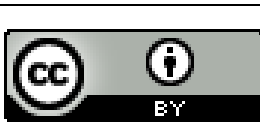


cocaine sensitization in mice. Neuropsychopharmacology 200328 2117-2123.

174 Akhisaroglu M, Ahmed R, Kurtuncu M, Manev H \& Uz T. Diurnal rhythms in cocaine sensitization and in Period1 levels are common across rodent species. Pharmacology, Biochemistry and Behavior 200479 37-42. (doi:10.1016/j.pbb.2004.06.014)

175 Sorg BA, Stark G, Sergeeva A \& Jansen HT. Photoperiodic suppression of drug reinstatement. Neuroscience $2011 \mathbf{1 7 6}$ 284-295. (doi:10.1016/ j.neuroscience.2010.12.022)

176 Andretic R, Chaney S \& Hirsh J. Requirement of circadian genes for cocaine sensitization in Drosophila. Science 1999285 1066-1068. (doi:10.1126/science.285.5430.1066)

177 Spanagel R, Pendyala G, Abarca C, Zghoul T, Sanchis-Segura C, Magnone MC, Lascorz J, Depner M, Holzberg D, Soyka M et al. The clock gene Per2 influences the glutamatergic system and modulates alcohol consumption. Nature Medicine 200511 35-42. (doi:10.1038/nm1163)

178 Perreau-Lenz S, Zghoul T \& Spanagel R. Clock genes running amok. Clock genes and their role in drug addiction and depression. EMBO Reports 20078 S20-S23. (doi:10.1038/sj.embor.7401016)

179 Falcón E \& McClung CA. A role for the circadian genes in drug addiction. Neuropharmacology 200956 (Suppl 1) 91-96. (doi:10.1016/j. neuropharm.2008.06.054)

180 Kovanen L, Saarikoski ST, Haukka J, Pirkola S, Aromaa A, Lonnqvist J \& Partonen T. Circadian clock gene polymorphisms in alcohol use disorders and alcohol consumption. Alcohol and Alcoholism 201045 303-311. (doi:10.1093/alcalc/agq035)

181 Albrecht U. The circadian clock, reward, and memory. Frontiers in Molecular Neuroscience 20114 41. (doi:10.3389/fnmol.2011.00041)

182 Malison RT, Kranzler HR, Yang BZ \& Gelernter J. Human clock, PER1 and PER2 polymorphisms: lack of association with cocaine dependence susceptibility and cocaine-induced paranoia. Psychiatric Genetics 2006 16 245-249. (doi:10.1097/01.ypg.0000242198.59020.ca)

183 Danel T \& Touitou Y. Alcohol consumption does not affect melatonin circadian synchronization in healthy men. Alcohol and Alcoholism 200641 386-390. (doi:10.1093/alcalc/agl036)

184 Danel T, Vantyghem MC \& Touitou Y. Responses of the steroid circadian system to alcohol in humans: importance of the time and duration of intake. Chronobiology International 200623 1025-1034. (doi:10.1080/07420520600920742)

185 Edwards AV \& Jones CT. Secretion of corticotrophin releasing factor from the adrenal during splanchnic nerve stimulation in conscious calves. Journal of Physiology 1988400 89-100.

186 Ehrhart-Bornstein M, Hinson JP, Bornstein SR, Scherbaum WA \& Vinson GP. Intraadrenal interactions in the regulation of adrenocortical steroidogenesis. Endocrine Reviews 199819 101-143. (doi:10. 1210/er.19.2.101)

187 Fukuda T, Takahashi K, Suzuki T, Saruta M, Watanabe M, Nakata T \& Sasano H. Urocortin 1, urocortin 3/stresscopin, and corticotropinreleasing factor receptors in human adrenal and its disorders. Journal of Clinical Endocrinology and Metabolism 200590 4671-4678. (doi:10.1210/jc.2005-0090)

188 Tsatsanis C, Dermitzaki E, Venihaki M, Chatzaki E, Minas V, Gravanis A $\&$ Margioris AN. The corticotropin-releasing factor (CRF) family of peptides as local modulators of adrenal function. Cellular and Molecular Life Sciences 200764 1638-1655. (doi:10.1007/s00018-007-6555-7)

189 van den Brink W \& van Ree JM. Pharmacological treatments for heroin and cocaine addiction. European Neuropsychopharmacology 200313 476-487. (doi:10.1016/j.euroneuro.2003.08.008)

190 Sabino V, Cottone P, Zhao Y, Steardo L, Koob GF \& Zorrilla EP. Selective reduction of alcohol drinking in Sardinian alcohol- preferring rats by a sigma-1 receptor antagonist. Psychopharmacology 2009205 327-335. (doi:10.1007/s00213-009-1548-x)

191 Moreno AY, Azar MR, Warren NA, Dickerson TJ, Koob GF \& Janda KD A critical evaluation of a nicotine vaccine within a self-administration behavioral model. Molecular Pharmaceutics 20107 431-441. (doi:10. 1021/mp900213u)

192 Koob GF \& Le Moal M. Drug addiction, dysregulation of reward, and allostasis. Neuropsychopharmacology 200124 97-129. (doi:10.1016/ S0893-133X(00)00195-0)

193 Miquel M, Toledo R, Garcia LI, Coria-Avila GA \& Manzo J. Why should we keep the cerebellum in mind when thinking about addiction? Current Drug Abuse Reviews 20092 26-40. (doi:10.2174/ 1874473710902010026)

194 Deroche V, Marinelli M, Le Moal M \& Piazza PV. Glucocorticoids and behavioral effects of psychostimulants. II: Cocaine intravenous selfadministration and reinstatement depend on glucocorticoid levels. Journal of Pharmacology and Experimental Therapeutics 1997281 1401-1407.

195 Piazza PV, Maccari S, Deminiere JM, Le Moal M, Mormede P \& Simon H. Corticosterone levels determine individual vulnerability to amphetamine self-administration. PNAS 199188 2088-2092. (doi:10.1073/pnas.88.6.2088)

196 Marinelli M, Rouge-Pont F, De Jesus-Oliveira C, Le Moal M \& Piazza PV. Acute blockade of corticosterone secretion decreases the psychomotor stimulant effects of cocaine. Neuropsychopharmacology 199716 156-161. (doi:10.1016/S0893-133X(96)00169-8)

197 Goeders NE \& Guerin GF. Effects of the combination of metyrapone and oxazepam on cocaine and food self-administration in rats. Pharmacology, Biochemistry and Behavior 200891 181-189. (doi:10. 1016/j.pbb.2008.07.005)

198 Shalev U, Marinelli M, Baumann MH, Piazza PV \& Shaham Y. The role of corticosterone in food deprivation-induced reinstatement of cocaine seeking in the rat. Psychopharmacology 2003168 170-176. (doi:10.1007/s00213-002-1200-5)

199 Barrot M, Abrous DN, Marinelli M, Rouge-Pont F, Le Moal M \& Piazza PV. Influence of glucocorticoids on dopaminergic transmission in the rat dorsolateral striatum. European Journal of Neuroscience 2001 13 812-818. (doi:10.1046/j.1460-9568.2001.01434.x)

200 Marinelli M, Rouge-Pont F, Deroche V, Barrot M, De Jesus-Oliveira C, Le Moal M \& Piazza PV. Glucocorticoids and behavioral effects of psychostimulants. I: Locomotor response to cocaine depends on basal levels of glucocorticoids. Journal of Pharmacology and Experimental Therapeutics 1997281 1392-1400.

201 Nelson AM, Kleschen MJ \& Zahniser NR. Individual differences in cocaine-induced locomotor activity of male Sprague-Dawley rats are not explained by plasma corticosterone levels. Neuroscience Letters 2010476 9-13. (doi:10.1016/j.neulet.2010.03.032)

202 Rose AK, Shaw SG, Prendergast MA \& Little HJ. The importance of glucocorticoids in alcohol dependence and neurotoxicity. Alcoholism, Clinical and Experimental Research 201034 2011-2018. (doi:10.1111/ j.1530-0277.2010.01298.x)

203 Fiancette JF, Balado E, Piazza PV \& Deroche-Gamonet V. Mifepristone and spironolactone differently alter cocaine intravenous selfadministration and cocaine-induced locomotion in C57BL/6J mice. Addiction Biology 201015 81-87. (doi:10.1111/j.1369-1600.2009. 00178.x)

204 Izawa R, Jaber M, Deroche-Gamonet V, Sillaber I, Kellendonk C, Le Moal M, Tronche F \& Piazza PV. Gene expression regulation following behavioral sensitization to cocaine in transgenic mice lacking the glucocorticoid receptor in the brain. Neuroscience 2006137 915-924. (doi:10.1016/j.neuroscience.2005.10.006)

Received in final form 24 May 2013

Accepted 31 May 2013 http://www.endocrineconnections.org

DOI: 10.1530/EC-13-0028 (c) 2013 The authors Published by Bioscientifica Ltd

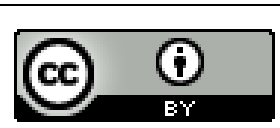

This work is licensed under a Creative Commons Attribution 3.0 Unported License. 